Journal of Agriculture and Natural Resources (2020) 3(1): 160-169

ISSN: 2661-6270 (Print), ISSN: 2661-6289 (Online)

DOI: https://doi.org/10.3126/janr.v3i1.27153

\title{
Research Article \\ Evaluation of open pollinated and hybrid maize varieties in Dhading district of Nepal
}

Shivahari Devkota ${ }^{1 *}$, Rupak Karn ${ }^{1}$, Ritesh Kumar Jha ${ }^{1}$, Dinesh Marasini ${ }^{1}$ and Shrawan Kumar Sah ${ }^{1}$

${ }^{1}$ Agriculture and Forestry University, Rampur, Chitwan, Nepal

*Corresponding email: devkota.shivahari@gmail.com

Orchid id: https://orcid.org/0000-0001-7587-0623

Received: August 25, 2019; Accepted: December 15, 2019; Published: January 7, 2020

(C) Copyright: Devkota et al. (2020).

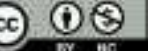

This work is licensed under a Creative Commons Attribution-Non Commercial 4.0 International License.

\begin{abstract}
Five maize varieties namely Rampur composite, Arun-2, Manakamana-3, Rampur Hybrid-4 and Rajkumar were evaluated in randomized complete block design with four replications at farmers field at Nilkantha Municipality-09, Aashikhola, Dhading from February 2018 to June 2018 to identify high yielding maze varieties. Significant variation was observed for grain yield, silking and tasseling, number of kernels per cob and cob length.The largest cob length was found in Rampur composite $(19.550 \mathrm{~cm})$ and highest number of kernel row per cob was found in Rajkumar (17.25) and Manakamana-3 (17.25).The highest number of leaves above cob was found in Rampur composite (5.678). The number of days for 50\% tasseling and number of days for 50\% silking had a highly significant and positive correlation with plot yield. The highest number of days for $50 \%$ tasseling (78.50 DAS) and days for $50 \%$ silking (82.50 DAS) was observed in the genotypes Rampur Hybrid-4. Similarly, the number of leaves above the cob, thousand kernel weight and length of the cob had a significant and positive correlation with plot yield. Rampur Hybrid -4 was the highest yielding genotype (7.79 $\mathrm{t} / \mathrm{ha}$ ) for such domain area with a B:C ratio of 1.48.Thus, Rampur Hybrid-4 genotype is recommended for spring season in Dhading.
\end{abstract}

Keywords: Maize, Spring, Genotypes, Rampur Hybid-4

Correct citation: Devkota, S., Karn, R., Jha, R. K., Marasini, D., \& Sah, S.K.(2020). Evaluation of open pollinated and hybrid maize varieties in Dhading district of Nepal. Journal of Agriculture and Natural Resources, 3(1), 160-169.

DOI: https://doi.org/10.3126/janr.v3i1.27153 
Journal of Agriculture and Natural Resources (2020) 3(1): 160-169

ISSN: 2661-6270 (Print), ISSN: 2661-6289 (Online)

DOI: https://doi.org/10.3126/janr.v3i1.27153

\section{INTRODUCTION}

Maize (Zea mays L.) is the second most important cereal crop after rice in Nepal, which is used as food, feed, fodder, and raw materials for industries as well. The cultivated area of maize is 891,583 ha. It's production id 2,231,517 t with the productivity of $2.5 \mathrm{t} / \mathrm{ha}$. Maize alone contributes $7.5 \%$ to national AGDP (MoAD, 2016). It is a major crop of hills in Nepal. It accounts for $72 \%$ maize production of the country (MoAD, 2016). The maize cultivation is the style for most of the farmers in the hills (Adhikariet al., 2003). It is grown in both irrigated low land and rainfed sloping area of hills. Maize has got the highest production potential among the crop plants and has wide variability in plant morphology. The present productivity of maize in Nepal is quite lower than that of other Asian countries. There is a wide gap between the potential yield of open-pollinated varieties having 5.0 t/ha (on station experimental yield), attainable yield of $3.5 \mathrm{t} / \mathrm{ha}$ (on farm yield with improved practices) and actual yield of $2.03 \mathrm{t} / \mathrm{ha}$ (national average yield) (Gurung \& Koirala, 2001).

Dhading shares account of 19,305 ha area for maize production. The total production of maize in this district is $37,967 \mathrm{t}$ with a productivity of $1.97 \mathrm{t} / \mathrm{ha}$ (DADO, 2072/73). The total area for spring maize is $4295 \mathrm{ha}$. The production and productivity of spring maize is $7629.8 \mathrm{t}$ and $1.78 \mathrm{t} / \mathrm{ha}$ respectively at Dhading which is far below than attainable yield (DADO, 2015/16). The farmers cultivated more OPV than maize hybrids in spring season due to high availability of OPV. Hence the present study is designed to study environment suitability for spring maize and also to recommend maize variety in Dhading. The aim of the study was to evaluate the performance of different genotypes of maize so as to find out suitable maize variety for spring season in Dhading district of Nepal

\section{MATERIALS AND METHODS}

\section{Experiment site}

The experiment was conducted in a farmer's field at Nilkantha Municipality -9, Aashikhola, Dhading. The altitude of the experimental site was 580 masl. Geographically, it was situated at $27^{\circ} 55^{\prime} 04.26^{\prime \prime}$ to $27^{\circ} 55^{\prime} 05.61^{\prime \prime}$ North latitude and $84^{\circ} 52^{\prime} 36.44^{\prime \prime}$ to $84^{\circ} 52^{\prime} 35.19^{\prime \prime}$ East longitude. The average annual temperature ranges between $15.1^{\circ} \mathrm{C}$ to $27.6^{\circ} \mathrm{C}$. The annual average rainfall of the district is $194 \mathrm{~mm}$.

\section{Plant materials}

Three OPV and a single Hybrid genotype provided by National Maize ResearchProgram, along with single Indian commercial Hybrid genotype were used for the field experiment in Dhading. The genotypes used were Rampur composite, Arun-2, Manakamana-3, Rampur Hybrid-4 and Rajkumar.

\section{Experimental design and cultural practices}

The experiment was planted in $11^{\text {th }}$ February, 2018 at Nilkantha Municipality-09, Aashikhola, Dhading district of Nepal in Randomized Complete Block Design (RCBD) with three replications. Along with FYM @ 10 t/ha, chemical fertilizers at the rate of 160:60:40 N: 
Journal of Agriculture and Natural Resources (2020) 3(1): 160-169

ISSN: 2661-6270 (Print), ISSN: 2661-6289 (Online)

DOI: https://doi.org/10.3126/janr.v3i1.27153

$\mathrm{P}_{2}: \mathrm{O}_{5}: \mathrm{K}_{2} \mathrm{O} \mathrm{kg} / \mathrm{ha}$ for hybrid varieties and 120:60:40 N: $\mathrm{P}_{2} \mathrm{O}_{5}: \mathrm{K}_{2} \mathrm{O} \mathrm{kg} / \mathrm{ha}$ for open pollinated varieties in the form of Urea. The DAP and Murate of Potash were applied during final land preparation. The half dose of Urea was applied at final land preparation and remaining half dose was used as top dress. Top dressing was done in two splits i.e. half dose at knee high stage and remaining half dose at just before tasseling stage. Individual plot size was $6.5 \times 3$ $\mathrm{m}^{2}$. Seed was shown @ 2 seeds/hills in $75 \mathrm{~cm}$ apart rows by maintaining $25 \mathrm{~cm}$ between hill to hill in a row. Thinning was done to maintain plant population after 3 weeks of germination. Intercultural operations were done as per recommendation of National Maize ResearchProgram.

\section{Data measurement}

Plant height, days to tasseling and silking, number of leaves, number of kernels/cob , cob length, thousand grain weight, and grain yield were recorded. Grain yield was estimated at $15 \%$ moisture and $80 \%$ shelling coefficient by formula which was also adopted by Carangal et al. (1971), Adhikari et al. (2018), Bartaula et al. (2019), Shrestha et al. (2018a) and Shrestha et al. (2018b).

\section{Cost of production}

Cost of cultivation of crop under each treatment was calculated based on the prevailing market for different inputs. Land preparation, Planting, weeding, fertilizer, harvesting, shelling, drying operation cost was included as a variable cost.

\section{Economic analysis}

The total cost for growing five maize genotypes was accounted. The gross income from each operation in terms of NRs. per hectare was calculated.

Gross income $=$ Yield $(\mathrm{kg} / \mathrm{ha})$ price per $\mathrm{kg}$

Total cost $=$ Cost of inputs, labors and machine used

Net return $=$ Gross income-total cost

$\mathrm{B}: \mathrm{C}$ ratio $=$ Gross income $/$ Total cost

\section{Statistical analysis}

All agronomic data from trials were analyzed using a split split-plot design ANOVA analysis. The experimental data were processed by using Excel 2016 and analyzed by using R-STAT version 3.4.4. The treatment means were compared by the Least Significant Difference (LSD) test at 5\% level (Gomez and Gomez, 1984; Shrestha, 2019).

\section{RESULTS AND DISCUSSION}

Analysis of variance (ANOVA) revealed non-significant differences among the genotypes for plant height. The value of plant height varied from $228.893 \mathrm{~cm}$ to $239.164 \mathrm{~cm}$ with a mean value of $233.996 \mathrm{~cm}$. Tallest height was found in the genotype Manakamana-3 $(239.164 \mathrm{~cm})$ followed by genotype Arun-2 $(236.188 \mathrm{~cm})$. These results are in accordance with the results presented by Ali (1994). The leaf number below ear ranges from 6.20 to 7.22 with the mean value 6.45. Analysis of variance revealed non-significant differences among genotypes for leaf number below the ear. The highest number of leaves was observed in the genotype Manakamana-3 (7.22). Least number of leaves was observed in Rajkumar (6.20) genotype. 
Journal of Agriculture and Natural Resources (2020) 3(1): 160-169

ISSN: 2661-6270 (Print), ISSN: 2661-6289 (Online)

DOI: https://doi.org/10.3126/janr.v3i1.27153

The number of leaves above ear varied from 5.11 to 5.67 with a mean value of 5.51. Analysis of variance revealed very highly significant differences among genotype for leaf number above the ear. The highest number of leaves was observed in the Rampur composite (5.67) followed by Rampur Hybrid-4 (5.64) and Manakamana-3 (5.62), The Arun-2 (5.114) showed the minimum number of leaves above the ear. The number of days for $50 \%$ tasseling varied from 58.25 to 78.50 with a mean value of 70.20 . Analysis of variance revealed very highly significant differences among genotype for the number of days for $50 \%$ tasseling. The highest number of days for $50 \%$ tasseling was observed in the genotypes Rampur Hybrid-4 (78.50) and Manakamana-3 (76.50) followed by genotype Rajkumar and Rampur composite with a number of days for $50 \%$ tasseling 7.25 and 66.5 respectively. The genotype Arun-2 showed the lowest number of days for $50 \%$ tasseling of 58.25 days. The number of days for $50 \%$ silking varied from 61.50 to 82.50 with a mean value of 73.8. Analysis of variance revealed very highly significant differences among genotype for leaf number above the cob . The highest number of days for 50\% silking was observed in the genotypes Rampur Hybrid (82.50) and Manakamana-3 (80.25). Least number of days for $50 \%$ silking appeared in Arun-2 (61.50). Similar results were also found by Prasai et al. (2014) and Kunwar et al. (2014)

Table 2. Mean performance of five genotypes for plant height, no of leaves below the ear , no of leaves above the ear, no of days for $50 \%$ tasseling, no of days for $50 \%$ silking

\begin{tabular}{lccccc}
\hline \multicolumn{1}{c}{ Genotypes } & $\begin{array}{c}\text { Plant Height } \\
(\mathrm{cm})\end{array}$ & $\begin{array}{c}\text { Leaves } \\
\text { below ear }\end{array}$ & $\begin{array}{c}\text { Leaves above } \\
\text { ear }\end{array}$ & $\begin{array}{c}\text { Days for 50\% } \\
\text { tasseling }\end{array}$ & $\begin{array}{c}\text { Days for 50\% } \\
\text { silking }\end{array}$ \\
\hline Rampur composite & 233.71 & 6.23 & $5.67^{\mathrm{a}}$ & $66.50^{\mathrm{c}}$ & $70.00^{\mathrm{c}}$ \\
Arun-2 & 236.18 & 6.34 & $5.11^{\mathrm{c}}$ & $58.25^{\mathrm{d}}$ & $61.50^{\mathrm{d}}$ \\
Manakamana-3 & 239.16 & 7.22 & $5.62^{\mathrm{ab}}$ & $76.50^{\mathrm{a}}$ & $80.25^{\mathrm{a}}$ \\
Rampur Hybrid-4 & 228.89 & 6.26 & $5.64^{\mathrm{ab}}$ & $78.50^{\mathrm{a}}$ & $82.50^{\mathrm{a}}$ \\
Rajkumar & 232.01 & 6.20 & $5.50^{\mathrm{b}}$ & $71.25^{\mathrm{b}}$ & $74.75^{\mathrm{b}}$ \\
\hline Grand mean & 233.99 & 6.45 & 5.51 & 70.20 & 73.80 \\
CV \% & 2.453 & 7.66 & 1.78 & 2.17 & 2.71 \\
LSD 0.05 & 8.846 & 0.76 & 0.15 & 2.35 & 3.09 \\
F-test & $\mathrm{Ns}$ & $\mathrm{Ns}$ & $* * *$ & $* * *$ & $* * *$ \\
SEM & 32.967 & 0.244 & 0.009 & 2.341 & 4.025 \\
\hline
\end{tabular}

$(* * *)$ indicates very highly significant differences at $0.1 \%$ level of significance, $(* *)$ indicates highly significant differences at $1 \%$ level of significance, $(*)$ indicates significant differences at $5 \%$ level of significance

\section{Grain yield and yield attributing traits}

The total plot yield varied from $12.87 \mathrm{~kg}$ to $17.02 \mathrm{~kg}$. Analysis of variance revealed highly significant differences among the genotype for total plot yield. The highest yield was observed in genotype Rampur Hybrid-4 (17.20 kg) followed by Rajkumar with plot yield of $15.195 \mathrm{~kg}$. Two genotypes Rampur composite (14.93) and Manakamana-3 (14.38) has performed better than Arun-2 (12.87 kg). Rampur composite and Rajkumar gave similar yield from LSD result.

The cob lengthvaried from $15.52 \mathrm{~cm}$ to $19.55 \mathrm{~cm}$ with a mean value of $17.33 \mathrm{~cm}$. Analysis of 
Journal of Agriculture and Natural Resources (2020) 3(1): 160-169

ISSN: 2661-6270 (Print), ISSN: 2661-6289 (Online)

DOI: https://doi.org/10.3126/janr.v3i1.27153

variance revealed significant differences among the genotype for cob length. The longest cob was found in genotype Rampur composite $(19.55 \mathrm{~cm})$ followed by genotype Rajkumar (18.02 $\mathrm{cm})$. Least cob lengthwas found to be in Arun-2 $(15.52 \mathrm{~cm})$.

Analysis of variance revealed highly significant differences among the genotypes for the number of kernel row per cob. Highest row number was found in the genotypes Manakamana-3 and genotype Rajkumar (17.25). The number of rows varied from 13.57 to 17.25 with a mean value of 15.9. Rampur composite (15.50) and Rampur Hybrid-4 (15.75) genotypes had a similar number of kernel row per cob . Arun-2 (13.75) genotype had the least number of kernel row per cob .

Table 3. Mean performance of five genotypes for plot yield, thousand kernel weight, cob length, and number of kernel row per cob

\begin{tabular}{|c|c|c|c|c|}
\hline Genotypes & Yield (kg/plot) & $\begin{array}{c}\text { Thousand Kernel } \\
\text { weight }(\mathrm{g})\end{array}$ & Cob length $(\mathrm{cm})$ & $\begin{array}{c}\text { No of kernel row } \\
\text { per cob }\end{array}$ \\
\hline Rampur composite & $14.93^{b}$ & 277.65 & $19.55^{\mathrm{a}}$ & $15.50^{\mathrm{ab}}$ \\
\hline Arun-2 & $12.87^{\mathrm{c}}$ & 256.32 & $15.52^{\mathrm{c}}$ & $13.75^{\mathrm{b}}$ \\
\hline Manakamana-3 & $14.32^{\mathrm{bc}}$ & 267.92 & $15.82^{b c}$ & $17.25^{\mathrm{a}}$ \\
\hline Rampur Hybrid-4 & $17.02^{\mathrm{a}}$ & 267.32 & $17.75^{\mathrm{abc}}$ & $15.75^{\mathrm{ab}}$ \\
\hline Rajkumar & $15.19^{\mathrm{ab}}$ & 246.95 & $18.02^{\mathrm{ab}}$ & $17.25^{\mathrm{a}}$ \\
\hline Grand mean & 14.87 & 263.23 & 17.33 & 15.9 \\
\hline $\mathrm{CV} \%$ & 8.49 & 6.86 & 8.61 & 9.43 \\
\hline $\mathrm{LSD}_{0.05}$ & 1.946 & 27.82 & 2.30 & 2.31 \\
\hline F-test & $* *$ & Ns & $*$ & $*$ \\
\hline SEM & 1.910 & 326.237 & 2.230 & 2.25 \\
\hline
\end{tabular}

(**) indicates highly significant differences at $1 \%$ level of significance, $(*)$ indicates significant differences at a $5 \%$ level of significance

Non-significant differences were observed among the genotypes studied for thousand kernel weight. The 1000-grain weight varied from $246.95 \mathrm{~g}$ to $277.65 \mathrm{~g}$ with a mean weight of 263.23 g. Highest weight was observed in Rampur composite whereas, least weight was observed in Rajkumar.

Existence of genetic variability among maize genotypes for yield and major yield attributing traits were reported by Bhusal et al. (2017), Kandel et al. (2018), Sharma et al. (2018) and Adhikary et al. (2018).

\section{Correlation Coefficient}

After the analysis of various traits of studied maize genotype, different correlation coefficient has been found. Plot yield showed positive significant correlation with thousand kernel weight $\left(0.447^{*}\right)$, leaves above the cob $\left(0.616^{*}\right)$, cob length $\left(0.553^{*}\right)$ whereas it showed highly significant correlation with the number of days for tasseling $\left(0.666^{* *}\right)$, number of days for silking $\left(0.670^{* *}\right)$. Plot yield showed negative but insignificant correlation with leaves below the cob (-0.162) and plant height (-0.265). Similarly, plot yield showed positive insignificant correlation with the number of kernel row per cob (0.287). This finding deviates 
Journal of Agriculture and Natural Resources (2020) 3(1): 160-169 ISSN: 2661-6270 (Print), ISSN: 2661-6289 (Online)

DOI: https://doi.org/10.3126/janr.v3i1.27153

for plant height and number of leaves below the cob with the findings of Saidaiah et al (2008). Also, Singh and Nigam (1977) found plot yield correlated to yield components, which is similar to the finding of this experiment. Also, from the study of Malhotra and Khehra (1986), grain yield was positively correlated with cob length, the number of kernel row per cob and thousand-grain weight. The result for days for tasseling and days for silking was found to be opposite as finding of Ashan (1999).

Thousand kernel weight showed positive and significant correlation with cob length $\left(0.553^{*}\right)$ and number of leaves above the cob $(0.480 *)$. The result showed a positive correlation of thousand kernel weight and plant height $(0.181)$, which is the different result as per the finding of Saidaiah et al (2008). Thousand-grain weights showed a positive correlation with the number of kernels per row (0.004).

Cob lengthshowed a highly significant correlation with the number of leaves above the cob $\left(0.594^{* *}\right)$ and positive correlation with the number of days for tasseling $(0.139)$ and the number of days for silking (0.130). Cob lengthshowed a negative correlation with plant height $(-0.031)$ and the number of leaves below the cob $(-0.336)$. Cob lengthhad a positive and significant correlation with plot yield $(0.553 *)$ and thousand kernel weight $(0.504 *)$. This result was similar to the finding of (Zarei et al., 2012) and Mohammadi et al. (2003).

Correlation of number of kernel row per cob with leaf number above the cob $\left(0.567^{* *}\right)$, number of days for tasseling $(0.597 * *)$, number of days for silking $\left(0.613^{* *}\right)$ was found highly significant. Correlation of the number of kernel row per cob with plant height and number of leaves below cob was found positively correlated. Correlation of the number of kernel row per cob was

Correlation of number of days for $50 \%$ tasseling with leaves above the cob $\left(0.744^{* * *}\right)$, number of days for silking $\left(0.996^{* * *}\right)$ and number of kernel row per cob $\left(0.597^{* *}\right)$ was found to be highly significant. The number of days for tasseling was negatively correlated with plant height (-0.144). The highest correlation was found between the number of days for tasseling and the number of days for the silking, contrasting result from a finding of Enujeke (2013). 
Journal of Agriculture and Natural Resources (2020) 3(1): 160-169

ISSN: 2661-6270 (Print), ISSN: 2661-6289 (Online)

DOI: https://doi.org/10.3126/janr.v3i1.27153

Table 4. Pcob son's correlation coefficients among different traits of maize genotypes, at Aashikhola, Dhading, 2018

\begin{tabular}{lccccccccc}
\hline \multicolumn{1}{c}{ LAE } & LBE & PH & DOT & DOS & PY & TKW & EL & NKRPE \\
\hline LNAE & 1 & & & & & & & & \\
LNBE & 0.177 & 1 & & & & & & & \\
PH & -0.024 & $0.510^{*}$ & 1 & & & & & & \\
DOT & $0.744^{* * *}$ & 0.230 & -0.144 & 1 & & & & & \\
DOS & $0.750^{* * *}$ & 0.245 & -0.126 & $0.996^{* * *}$ & 1 & & & & \\
PY & $0.616^{*}$ & -0.162 & -0.265 & $0.666^{* *}$ & $0.670^{* *}$ & 1 & & & \\
TKW & $0.480^{*}$ & 0.035 & 0.181 & 0.164 & 0.157 & $0.447^{*}$ & 1 & & \\
EL & $0.594^{* *}$ & -0.336 & -0.031 & 0.139 & 0.130 & $0.553^{*}$ & $0.504^{*}$ & 1 & \\
NKRPE & $0.567^{* *}$ & 0.224 & 0.122 & $0.597^{* *}$ & $0.613^{* *}$ & 0.287 & 0.004 & 0.068 & 1 \\
\hline
\end{tabular}

LAE: Leaf above cob ; LBE: leaf below cob ; PH: Plant Height; DOT: No of days for $50 \%$ tasseling; DOS: no of days for 50\% silking; PY: yield/plot; TWK: Thousand kernel weight; EL: Length of cob ; NKRPE: No of kernel row per cob $(* * *)$ indicates highly significant differences at $0.1 \%$ level of significance, $(* *)$ indicates highly significant differences at $1 \%$ level of significance, $(*)$ indicates significant differences at a $5 \%$ level of significance

\section{Economic Analysis}

Economic analysis showed that gross farm gate benefit was highest for Rampur Hybrid-4 (Rs.251372.30) followed by Rajkumar (Rs. 224418.44) genotype. Least gross farm gate benefit was for Arun-2 (Rs. 190198.14). Total input cost of maize production was observed highest for Rampur Hybrid-4 (Rs. 101332), whereas the least operational cost is for Arun-2 (Rs. 92549.2). Net benefit from production was observed highest for Rampur Hybrid-4 (Rs. 150040.30) with B:C ratio of 1.4806. Followed to Rampur Hybrid-4, Rampur composite had net benefit Rs. 125484.92 and B:C ratio 1.3202 .

The marginal rate of return was highest for substitution of Rajkumar by Rampur Hybrid-4 i.e. 21.4615. Similarly, the substitution of Rampur composite by Rampur Hybrid-4 gave a marginal rate of return of 3.9083. But the marginal rate of return was -0.2357 observed when Rampur composite was substituted by Rajkumar genotype. Similarly, Rajkumar, Manakamana-3, Arun-2 genotypes had B:C ratio 1.241,1.223 and 1.055 respectively. 
Journal of Agriculture and Natural Resources (2020) 3(1): 160-169

ISSN: 2661-6270 (Print), ISSN: 2661-6289 (Online)

DOI: https://doi.org/10.3126/janr.v3i1.27153

Table 5. Cost of production evaluation and economic analysis of maize production for genotypes, 2018

\begin{tabular}{|c|c|c|c|c|c|}
\hline & \multicolumn{5}{|c|}{ Maize varieties } \\
\hline & \multicolumn{2}{|l|}{ Rampur } & Manakamana & \multicolumn{2}{|l|}{ Rampur } \\
\hline & Composite & Arun-2 & -3 & Hybrid-4 & Rajkumar \\
\hline \multicolumn{6}{|c|}{ 1.Gross farm gate benefits } \\
\hline $\begin{array}{l}1.1 \text { Average } \\
\text { production(kg/ha) }\end{array}$ & 7657.435 & 6604.102 & 7347.692 & 8728.205 & 7792.307 \\
\hline 1.2 Adjusted yield (kg/ha) & 6801602 & 5043607 & 6612023 & 7855385 & 70130763 \\
\hline 1.3 Price (Rs. $/ \mathrm{kg}$ ) & 32 & $\begin{array}{l}5945.092 \\
32\end{array}$ & $\begin{array}{c}6612.923 \\
32\end{array}$ & $\begin{array}{l}055.385 \\
32\end{array}$ & $\begin{array}{l}1015.0 / 03 \\
32\end{array}$ \\
\hline 1. Gross farm gate benefits & 220534.13 & 190198.14 & 211613.53 & 251372.30 & 224418.44 \\
\hline \multicolumn{6}{|c|}{ 2. Variable Input costs } \\
\hline Land lease cost & 15000 & 15000 & 15000 & 15000 & 15000 \\
\hline Land preparation cost & 20000 & 20000 & 20000 & 20000 & 20000 \\
\hline Maize seeds & 2212.5 & 2212.5 & 2320 & 6000 & 5100 \\
\hline Planting & 12000 & 12000 & 12000 & 12000 & 12000 \\
\hline Fertilizer & 13836.7 & 13836.7 & 13836.7 & 15832 & 15832 \\
\hline Weeding & 16000 & 16000 & 16000 & 16000 & 16000 \\
\hline Harvesting & 6000 & 5000 & 6000 & 6000 & 6000 \\
\hline Shelling & 6000 & 5000 & 6000 & 6000 & 6000 \\
\hline Drying & 4000 & 3500 & 4000 & 4500 & 4200 \\
\hline 2. Total input costs & 95049.2 & 92549.2 & 95156.7 & 101332 & 100132 \\
\hline 3. Net Benefit & 125484.92 & 97648.94 & 116456.83 & 150040.30 & 124286.44 \\
\hline \multirow[t]{3}{*}{ Change in the net benefit } & & -27835.99 & 18807.89 & $\begin{array}{r}33583.474 \\
52301.264\end{array}$ & -25753.862 \\
\hline & & & -9028.098 & 52391.3664 & 7829.612 \\
\hline & & & & 24555.376 & $\begin{array}{l}26637.504 \\
-1198.486\end{array}$ \\
\hline Total variable input & 95049.2 & 92549.2 & 95156.7 & 101332 & 100132 \\
\hline \multirow[t]{4}{*}{ Change in total input costs } & & -2500 & 2607.5 & 6175.3 & -1200 \\
\hline & & & 107.5 & 8782.8 & 4975.3 \\
\hline & & & & 6282.8 & 7582.8 \\
\hline & & & & & 5082.8 \\
\hline \multirow[t]{4}{*}{ 4. Marginal rate of return } & & 11.1343 & 7.2129 & 5.4383 & 21.4615 \\
\hline & & & -83.9823 & 5.9652 & 1.5736 \\
\hline & & & & 3.9083 & 3.5128 \\
\hline & & & & & -0.2357 \\
\hline 5. B:C ratio & 1.3202 & 1.05510 & 1.2238 & 1.4806 & 1.2412 \\
\hline
\end{tabular}

\section{CONCLUSION}

After the analysis of different traits, maize genotype Rampur hybrid-4 was found to be high yielding and most beneficial as compared to other maize genotypes. Rampur composite genotype was statistically similar to Rajkumar genotype. The B:C ratio and marginal rate of return suggested that Rampur composite was better-benefiting genotype as compared to Rajkumar genotype. Due to the scarcity of Rampur Hybrid-4 seed, Rampur composite is recommended to cultivate in Maize zone command area. Successful production of spring maize from the experiment helped to conclude that, spring maize can be grown on fallow 
Journal of Agriculture and Natural Resources (2020) 3(1): 160-169

ISSN: 2661-6270 (Print), ISSN: 2661-6289 (Online)

DOI: https://doi.org/10.3126/janr.v3i1.27153

river basin marginal land under PM-AMP (Maize-zone). There was sandy soil with a slightly acidic reaction $(\mathrm{pH}$ 6.5). Scientific agronomic practices of maize were developed and disseminated to all members of PM-AMP (Maize-zone).

\section{ACKNOWLEDGMENTS}

We are thankful to and Agriculture and Forestry University for the financial support and Professor Dr. Shrawan Kumar Sah for his regular guidance.

\section{Authors contribution}

S. Devkota

R. Karn

R. K. Jha

D. Marassini

S.K. Sah
Performed experiment, analysed data and wrote the paper Design and performed experiment, analysed data and wrote and edit paper Performed experiment and helps in data recording Helped in experiment and data recording supervised the experiment and helped in manuscript writing

\section{Conflict of interest}

The authors declare that there is no conflicts of interest regarding publication of this manuscript.

\section{REFERENCES}

Adhikari, B. N., Shrestha, J., Dhakal, B., Joshi, B. P., \& Bhatta, N. R. (2018). Agronomic performance and genotypic diversity for morphological traits among cob ly maize genotypes. International Journal of Applied Biology, 2(2), 33-43.

Ali, Z. (1994). Studies on comparative economic returns of different maize genotypes (Doctoral dissertation, M. Sc. Thesis, Deptt. Agron., Univ. Agri., Faisalabad)

Ashan , M. (1999). Performance of Six Maize (Zea mays L.) Inbred Lines and Their all Possible as Well as Reciprocal Cross Combinations.

Bartaula, S., Panthi, U., Timilsena, K., Acharya, S., \& Shrestha, J. (2019). Variability, heritability and genetic advance of maize (Zea mays L.) genotypes. Research in Agriculture Livestock and Fisheries, 6(2), 163-169.

Bhusal, T., Lal, G.M., Marker, S., \& Synrem, G.J.(2017). Genetic variability and traits association in maize (Zea mays L.) genotypes. Annals of Plants and Soil Research, 19(1), 59-65.

Carangal, V.R., Ali, S.M., Koble, A.F., Rinke, E.H. \& Sentz, J.C. 1971. Comparison of S1 with testcross evaluation for recurrent selection in maize. Crop Science, 11, 658-661.

DADO, D. A. (2015/16). Annual Agriculture Development program. Dhading: DADO.

Enujeke, E. C. (2013). Effects of Variety and Spacing on Growth Characters of Hybrid Maize. Asian Journal of Agriculture and Rural Development, 3(5), 296-310.

Gomez, K. A., \& Gomez, A. A. (1984). Statistical Procedure for Agricultural Research(2 ${ }^{\text {nd }}$ 
Journal of Agriculture and Natural Resources (2020) 3(1): 160-169

ISSN: 2661-6270 (Print), ISSN: 2661-6289 (Online)

DOI: https://doi.org/10.3126/janr.v3i1.27153

edn.). Int. Rice Res. Inst. andWilley, New York pp. 28-192.

Gurung, D., \& Koirala, K. (2001). Maize landraces form the mid and far western hills of Nepal: an exploration and evaluation for cultivar development. Proceedings of a maize symposium, 3-5 December 2001, Kathmandu, Nepal., pp 75-81.

Kandel, M., Ghimire, S. K., Ojha, B. R., \& Shrestha, J. (2018). Correlation and path analysis for grain yield and its attributing traits of maize inbred lines (Zea mays L.) under heat stress condition. International Journal of Agriculture, Environment and Food Sciences, 2(4), 124-130.

Kunwar, C.B., Bhurer, K.P., Paudel, S.P., Chhetri, J.B., \& Shrestha, J. (2014). Cob ly and extra cob ly maturity maize variety for terai, inner terai and foot hill of Nepal. In: Giri, Y.P., Khadka,Y.G., Mahato, B.N., Sah, B.P., Khatiwada, S.P., Bhatta, M.R., Chettri, B.K., Gautam, A.K., Gauchan, D., Ansari, A.R., Ranjit, J.D., Shrestha, R., \& Sapkota, B. (eds). Proceedings of the 27th National Summer Crops Workshop, Vol. II, held on 18-20th April, 2013 at National Maize ResearchProgram, Rampur, Chitwan, 78-81.

MOAD. (2014). Statistical information on nepalese agriculture. Singhdurbar, kathmandu. Nepal: Government of Nepal, Ministry of Agricultural Development, Agribussiness Promotion and Statistics Division.

MoAD. (2016). Statistical information on nepalese agriculture. Singhdurbar, kathmandu. Nepal: Government of Nepal, Ministry of Agricultural Development, Agribussiness Promotion and Statistics Division.

MOAD. (2018). Statistical Information on Nepalese Agriculture. Hariharbhawan, Lalitpur: Ministry of Agriculture and Livestock Development.

Prasai, H.K., Kushwaha, U.K.S., Joshi, B.P., \& Shrestha, J. (2015). Performance evaluation of cob ly maize genotypes in far western hills of Nepal. Journal of Maize Research and Development, 1(1), 106-111.

Ranum, P., Pena-Rosas, J. P., \& Garcia-Casal, M. N. (2014). Global maize production, utilization, and consumption. Annals of the New York Academy of Scienses, 105-112.

Saidaiah, P., Satyanarayana , E., \& Kumar, S. (2008). Association and path analysis coefficient in maize (Zea mays L). Agric. Sci. Digest, 28(2), $79-83$.

Sharma, B.K., Sharma, S., Kandel, B.P., \& Shrestha, J. (2018). Varietal evaluation of promising maize genotypes. Azarian Journal of Agriculture, 5(4), 120-124.

Shrestha, J., Yadav, D.N., Amgain, L.P. \& Sharma, J. P. 2018a. Effects of nitrogen and plant density on maize (Zea mays L.) phenology and grain yield. Current Agriculture Research Journal, 6(2), 175-182.

Shrestha, J., Kunwar, C. B., \& Bhandari, B. 2018b. Response of mass selection in maize (Zea mays L.). Our Nature, 16(1), 35-42.

Shrestha, J. (2019). P-Value: A true test of significance in agricultural research. Retrieved from https://www.linkedin.com/pulse/p-value-test-significance-agricultural-researchjiban-shresthal

Adhikari, K., Paudyal, K., \& Ransom, J. (December 2003). Adoption of Improved maize varieties in the hills of Nepal. Agricultural Economics, pp 299-305. 